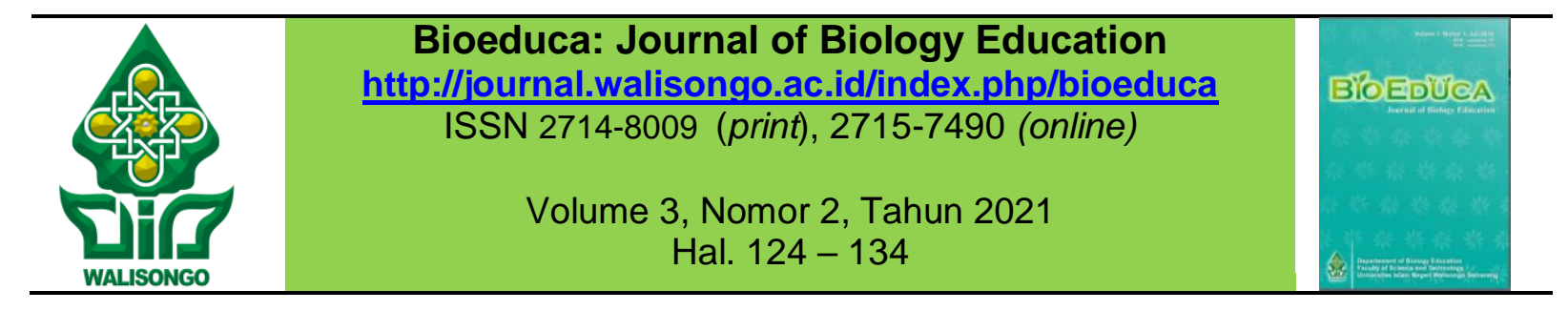

\title{
Teknologi Augmented Reality (Ar) Sebagai Solusi Media Pembelajaran Sains Di Masa Adaptasi Kebiasaan Baru
}

\author{
Juwita ${ }^{1}$, Elania Zoela Saputri ${ }^{2}$, Ira Kusumawati ${ }^{3}$ \\ 1,2,3, Program Studi Pendidikan Biologi, Universitas Ahmad Dahlan Yogyakarta \\ Email : juwita1800008077@webmail.uad.ac.id
}

\begin{tabular}{|c|c|}
\hline Informasi Artikel & ABSTRAK \\
\hline $\begin{array}{l}\text { Submit: } 19-10-2020 \\
\text { Diterima: } 15-09-2021 \\
\text { Dipublikasikan: } 15-09-2021\end{array}$ & $\begin{array}{l}\text { Media pembelajaran dengan teknologi Augmented Reality (AR) } \\
\text { dapat memberikan kesempatan kepada peserta didik secara } \\
\text { langsung untuk belajar dimanapun dan kapanpun. Penelitian ini } \\
\text { menggunakan pendekatan kualitatif melalui metode penelitian } \\
\text { studi literatur dengan mencari referensi berupa artikel yang } \\
\text { relevan dari jurnal dan sumber pustaka lainnya. Data yang } \\
\text { diperoleh adalah data sekunder yang selanjutnya dianalisis } \\
\text { dengan metode deskriptif. Teknologi Augmented Reality (AR) } \\
\text { merupakan sebuah teknologi yang dapat dimanfaatkan sebagai } \\
\text { media pembelajaran dengan cara menggabungkan objek visual } \\
\text { dua maupun tiga dimensi. Teknologi AR dapat dihadirkan ke } \\
\text { dalam dunia nyata dan dimunculkan secara real time. Teknologi } \\
\text { tersebut dapat digunakan dalam pembelajaran Biologi berbasis } \\
\text { praktikum dan pembelajaran Fisika dalam materi tata surya. } \\
\text { Penggunaan teknologi Augmented Reality (AR) sebagai media } \\
\text { pembelajaran sains telah terbukti dapat meningkatkan hasil } \\
\text { belajar peserta didik. Agar pemanfaatan teknologi Augmented } \\
\text { Reality (AR) sebagai media pembelajaran lebih efektif maka } \\
\text { diperlukan- upaya pengembangan teknologi Augmented Reality } \\
\text { (AR) pada materi pelajaran yang membutuhkan visualisasi objek } \\
\text { misalnya pada materi Sistem Pernapasan dan Sistem Peredaran } \\
\text { Darah. } \\
\text { Kata kunci: adaptasi kebiasaan baru; Augmented Reality }\end{array}$ \\
\hline Penerbit & ABSTRACT \\
\hline $\begin{array}{l}\text { Program Studi Pendidikan } \\
\text { Biologi, Fakultas Sains dan } \\
\text { Teknologi, UIN Walisongo } \\
\text { Semarang }\end{array}$ & $\begin{array}{l}\text { Learning media with Augmented Reality (AR) technology can } \\
\text { provide opportunities for students directly to learn anywhere and } \\
\text { anytime. This study uses a qualitative approach through literature } \\
\text { study research methods by looking for references in the form of } \\
\text { relevant articles from journals and other library sources. The data } \\
\text { obtained is secondary data which is then analyzed by descriptive } \\
\text { method. Augmented Reality (AR) technology is a technology that } \\
\text { can be used as a learning medium by combining two- or three- } \\
\text { dimensional visual objects. AR technology can be brought into } \\
\text { the real world and displayed in real time. This technology can be } \\
\text { used in practicum-based Biology learning and Physics learning in } \\
\text { the solar system. The use of Augmented Reality (AR) technology } \\
\text { as a science learning media has been proven to improve student } \\
\text { learning outcomes. In order for the use of Augmented Reality } \\
\text { (AR) technology as a learning media to be more effective, it is } \\
\text { necessary to develop Augmented Reality (AR) technology on } \\
\text { subject matter that requires object visualization, for example in }\end{array}$ \\
\hline
\end{tabular}




\section{PENDAHULUAN}

Desember Tahun 2019, telah teridentifikasi adanya wabah virus baru. Seiring dengan pesatnya penyebaran virus ini maka masyarakat mengenalnya dengan nama Coronavirus Disease 019 atau sering disebut dengan COVID-19, nama tersebut dicetuskan secara resmi oleh organisasi kesehatan dunia atau kita kenal dengan World Health Organization (WHO) (Direktorat Jenderal Pencegahan dan Pengendalian Penyakit, 2020). COVID-19 merupakan virus dengan kategori penularannya masuk ke dalam kelas B dimana penularan ini menyebabkan banyak korban meninggal atau cacat walau akibatnya lebih ringan dari yang pertama (Irwan, 2017 dalam Safrizal, dkk. 2020). Seiring penyebaran virus COVID-19 yang terus meningkat di seluruh dunia maka WHO menetapkan COVID-19 sebagai pandemi pada 9 Maret 2020. Pandemi ini memberikan dampak pada berbagai sektor, seperti perekonomian, pemerintahan, perilaku manusia hingga sektor pendidikan.

Sebagai upaya mengurangi angka positif penderita COVID-19 di Indonesia, pemerintah telah membuat beberapa kebijakan. Salah satu kebijakan pemerintah adalah memberlakukan Work From Home (WFH) yang diatur dalam SE MENPAN RB 58/2020 dimana kebijakan tersebut membawa pengaruh yang besar terhadap aktivitas masyarakat Indonesia termasuk aktivitas di dunia pendidikan. Kebijakan pemerintah yang memberikan arahan untuk belajar dari rumah baik tingkat sekolah/madrasah maupun perguruan tinggi sampai batas waktu yang belum ditentukan cukup mengejutkan masyarakat. Selain itu pemerintah juga memutuskan untuk memindahkan proses pembelajaran yang semula berupa pembelajaran luar jaringan atau biasa disebut luring menjadi pembelajaran dalam jaringan atau lebih dikenal dengan istilah daring.Keputusan pemerintah tersebut membuat kebingungan banyak pihak seperti guru, orang tua, dan juga peserta didik, terutama di desa-desa yang infrastruktur informasi dan teknologinya belum memadai untuk dilakukannya pembelajaran secara daring (Prawanti, 2020).

Kebijakan menyelenggarakan pembelajaran daring di masa pandemi COVID19 menimbulkan beberapa permasalah seperti penguasaan teknologi yang masih rendah, jaringan internet yang belum merata, menurunnya minat belajar peserta didik, keterbatasan sarana dan prasarana serta biaya pembelian kuota internet yang semakin melonjak menjadi topik utama bagi masyarakat di dalam pembelajaran daring (Basar, 2021). Oleh karena itu, pendidikan di masa pandemi COVID-19 menjadi tantangan yang sangat besar bagi seluruh elemen masyarakat di Indonesia. Kini di Indonesia telah menggunakan istilah "adaptasi kebiasaan baru" yang menganjurkan masyarakat untuk menerapkan protokol kesehatan dalam setiap aktivitasnya. Sejak diberlakukannya masa adaptasi kebiasaan baru aktivitas-aktivitas masyarakat seperti perekonomian dan perkantoran mulai berjalan normal seperti biasanya tidak terkecuali aktivitas di dunia pendidikan.Para guru diwajibkan untuk datang ke sekolah dan presensi seperti biasanya, bahkan Peserta didik dan pendidik 
yang saat ini berada di zona kuning dan hijau bisa memulai pembelajaran tatap muka. Namun untuk peserta didik dan pendidik yang berada di zona oranye dan merah harus tetap melaksanakan pembelajaran dari rumah. Hal tersebut berdasarkan Surat Keputusan Bersama (SKB) Empat Menteri tentang Panduan Penyelenggaraan Pembelajaran Pada Tahun Ajaran 2020/2021 dan Tahun Akademik 2020/2021 Di Masa Pandemi CoronaVirus Diseases 2019 (Covid-19).

Sebagai upaya memaksimalkan proses pembelajaran di masa adaptasi tersebut, guru dituntut untuk menyajikan materi pelajaran dengan lebih kreatif dan inovatif sehingga tujuan dan kualitas pembelajaran tetap bermutu. Terlebih lagi pembelajaran sains yang tidak lepas dari kegiatan mengamati lingkungan sekitar, eksplorasi, dan praktikum. Augmented Reality (AR) merupakan sebuah teknologi yang dapat menjadi solusi dalam permasalahan yang sedang dihadapi dalam dunia pendidikan. Augmented Reality (AR) merupakan sebuah teknologi berupa aplikasi penggabungan dunia nyata dengan dunia maya dalam bentuk dua dimensi maupun tiga dimensi yang diproyeksikan dalam sebuah lingkungan nyata dalam waktu yang bersamaan. Augmented Reality sering juga disebut dengan realitas terhambat (Mustaqim, 2017:37), karena Augmented Reality menambahkan objek maya ke dalam objek nyata dalam waktu yang bersamaan. Adanya Augmented Reality (AR) dapat menjadi solusi permasalahan pembelajaran sains khususnya untuk menampilkan objek pembelajaran di dalam kelas agar lebih interaktif dan efektif. Augmented Reality (AR) yang dapat diimplementasikan secara luas dalam berbagai media, mudah untuk dioperasikan serta pembuatan yang tidak memakan terlalu banyak biaya membuat Augmented Reality (AR) menjadi solusi media pembelajaran di masa adaptasi kebiasaan baru (Mustaqim, 2017:37). Adapun tujuan dari penelitian ini adalah untuk mengetahui kondisi pembelajaran sains di masa adaptasi kebiasaan baru, mengetahui peran teknologi Augmented Reality (AR) sebagai solusi media pembelajaran sains di masa adaptasi kebiasaan baru, serta mengetahui contoh implementasi teknologi Augmented Reality (AR) sebagai solusi media pembelajaran sains di masa adaptasi kebiasaan baru.

\section{METODE PENELITIAN}

Penelitian menggunakan pendekatan deskriptif kualitatif. Hal tersebut karena sumber data yang diperoleh berupa deskripsi kata- kata. Jenis penelitian yang digunakan adalah kepustakaan atau riset pustaka. Jenis penelitian ini digunakan untuk mengumpulkan data yang berkaitan dengan objek penelitian yang bersifat kepustakaan. Sebagaimana yang dinyatakan oleh Zed (2014), pada riset pustaka (library research), penelusuran pustaka tidak hanya untuk langkah awal menyiapkan kerangka penelitian (research design) akan tetapi sekaligus memanfaatkan sumbersumber perpustakaan untuk memperoleh sumber data penelitian.

Sumber data yang diperoleh dari penelitian ini adalah data primer dan data sekunder. Menurut Sugiyono (2016), Data primer dihasilkan dari jurnal kepustakaan yang telah dikumpulkan, sedangkan data sekunder dihasilkan dari referensi buku 
maupun website yang relevan dengan topik pembahasan. Setelah diperoleh data primer dan data sekunder kemudian dilakukan triangulasi atau penggabungan sumber data.

Langkah awal yang perlu dilakukan untuk memperoleh data-data dari berbagai sumber data yaitu dengan cara mengumpulkan sumber data. Dalam penelitian ini, sumber data yang digunakan berasal dari 30 jurnal terbaru dengan kriteria yang dipilih adalah artikel yang relevan dengan topik pembahasan. Jurnal yang sudah dikumpulkan kemudian dibuat ringkasan mulai dari nama jurnal, jenis jurnal, judul jurnal, tahun terbit, tempat penelitian, tujuan penelitian, metode penelitian, hasil penelitian dan juga sumber jurnal baik URL maupun DOI. Ringkasan jurnal tersebut selanjutnya dimasukkan ke dalam format tabel yang diurutkan sesuai tahun terbit. Kata kunci yang digunakan untuk mencari artikel adalah Media Pembelajaran Augmented Reality (AR), Pembelajaran Daring, Pembelajaran Sains. Adaptasi Kebiasaan Baru.

Setelah semua data terkumpul. selanjutnya dilakukan analisis data. Dalam penelitian ini analisis data yang digunakan adalah analisis data berdasarkan isi penelitian. Menurut (Sofiah et al., 2020), Analisis isi (content analysis) adalah pembahasan yang bersifat mendalam terhadap isi dari suatu informasi yang berbentuk cetak maupun non cetak. Adapun tahap- tahap analisis isi terdiri dari enam langkah diantaranya (1) unitizing atau menyatukan, mengidentifikasi data yang digunakan sebagai sumber data penelitian. (2) sampling atau pengambilan informasi penting agar data yang tersaji menjadi spesifik, (3) reducing atau proses pemilihan data yang penting, (4) inferring atau menarik kesimpulan dari berbagai sumber data yang telah direduksi, (5) analyzing atau menganalisis data yang sudah ditemukan dan yang terakhir adalah (6) narrating atau penyajian data sebagai hasil penelitian (Yuliani, 2017).

\section{HASIL PENELITIAN DAN PEMBAHASAN}

Menurut Kementrian Dalam Negeri, (2020) sistem pembelajaran daring membawa beberapa pergeseran antara lain, Pergeseran metode belajar, Pergeseran metode pembelajaran, Pergeseran tanggung jawab dalam proses belajar mengajar, serta pergeseran dalam evaluasi pembelajaran. Dari keempat pergeseran tersebut, keberadaan teknologi bagi dunia pendidikan merupakan sarana yang dapat dipakai sebagai media penyampaian program pembelajaran baik secara searah maupun secara interaktif (Husaini, 2019 ). Proses belajar tidak lagi dibatasi oleh ruang kelas tertentu (Denker, 2013). Selain itu penggunaan teknologi telah memungkinkan munculnya pembelajaran jarak jauh dan mendorong inovasi yang lebih besar dalam menciptakan metode pengajaran di dalam dan di luar kelas (Almeida, 2019) dalam (Fitriani, 2020:166). Seiring dengan berkembangnya teknologi maka kita dapat memanfaatkan teknologi sebagai media pembelajaran.

Peran media pembelajaran dalam proses pembelajaran merupakan suatu kesatuan yang tidak dapat dipisahkan dalam suatu pendidikan. Lautfer menyatakan bahwa media pembelajaran adalah salah satu alat bantu mengajar bagi guru untuk 
menyampaikan materi pengajaran, meningkatkan kreativitas siswa dan meningkatkan perhatian siswa dalam proses pembelajaran (Tafonao, 2018). Dengan demikian guru dituntut untuk lebih kreatif dan inovatif dalam penggunaan media pembelajaran. Pada masa adaptasi kebiasaan baru,guru bukan hanya harus mampu mengajar dengan menyampaikan materi kepada siswa saja namun guru dituntut untuk pandai dalam penggunaan teknologi karena media pembelajaran pada masa adaptasi kebiasaan baru sangat bergantung dengan perkembangan teknologi,

Salah satu teknologi interaktif yang digunakan dalam pembelajaran yang dapat digunakan adalah teknologi Augmented Reality (AR). Menurut Furht (2011: 3) dalam Yuliono (2018) menyatakan bahwa, Augmented Reality (AR) adalah teknologi yang menggabungkan objek virtual dua dimensi maupun tiga dimensi ke dalam sebuah lingkungan nyata lalu memproyeksikan objek-objek virtual tersebut secara real time. Selaras dengan pendapat tersebut, Bhoyroo (2016:125) dalam (Yuliono, 2018) mendefinisi AR sebagai media virtual yang dihasilkan komputer informasi ditumpangkan pada gambar nyata ke suatu objek. Berdasarkan pengertian Augmented Reality (AR) di atas dapat disimpulkan bahwa teknologi Augmented Reality (AR) merupakan sebuah teknologi yang dapat dikembangkan sebagai alternatif media pembelajaran dengan menggabungkan dunia nyata dengan dunia maya dalam bentuk objek visual dua maupun tiga dimensi ke dalam lingkungan nyata, produk akhir dari teknologi Augmented Reality (AR) dapat diproyeksikan secara real time.

Teknologi Augmented Reality (AR) tentunya memiliki kekurangan dan kelebihan. Menurut (Mustaqim, 2017:37) kelebihan dari Augmented Reality adalah lebih interaktif, efektif dalam penggunaan, dapat diimplementasikan secara luas dalam berbagai media, modeling objek yang yang sederhana, karena hanya menampilkan beberapa objek, pembuatan yang tidak memakan terlalu banyak biaya, serta mudah untuk dioperasikan. Sedangkan kekurangan dari Augmented Reality (AR) adalah sensitif dengan perubahan sudut pandang, pembuat belum terlalu banyak, dan membutuhkan banyak memori pada peralatan yang dipasang. Proses pembelajaran sains tidak lepas dari materi abstrak sehingga dibutuhkan pengalaman belajar untuk memahami konsep dan pemahaman sains. Salah satu cara untuk meningkatkan pengalaman belajar siswa yaitu melalui pelaksanaan model pembelajaran praktikum. Pada situasi Pembelajaran Jarak Jauh seperti saat ini kegiatan praktikum dapat dilaksanakan dengan memanfaatkan teknologi Augmented Reality (AR).

Teknologi Augmented Reality (AR) dapat diimplementasikan pada pembelajaran sains khususnya pada pembelajaran yang membutuhkan visualisasi objek, seperti materi sel, virus, sistem pada tubuh manusia, planet dan lain-lain. Penggunakan teknologi Augmented Reality (AR) dapat digunakan pada peserta didik mulai jenjang SD sampai SMA, meskipun memiliki karakteristik yang berbeda. Dikutip dari (Dewi, 2019), menyebutkan bahwa karakteristik peserta didik jenjang SD antara lain, peserta didik di jenjang SD menyukai proses pembelajaran yang bermuatan permainan sehingga menuntut guru SD untuk melaksanakan kegiatan 
pembelajaran yang bermuatan permainan. Selain itu peserta didik pada jenjang SD senang merasakan atau melakukan dan memperagakan sesuatu secara langsung, sehingga guru hendaknya merancang model pembelajaran yang memungkinan peserta didik untuk terlibat langsung dalam proses pembelajaran. Karakteristik peserta didik jenjang SMP mereka lebih memiliki rasa penasaran yang tinggi serta emosional yang tinggi sehingga untuk mencapai kematangan emosi, remaja harus belajar memperoleh gambaran tentang situasi yang dapat menimbulkan reaksi emosional, sehingga guru harus lebih kreatif dalam menyampaikan materi. Aktivitas proses pembelajaran yang dilakukan menghubungkan antara apa yang telah mereka ketahui dengan apa yang akan mereka pelajari (Kementerian Pendidikan Nasional, 2016), Karakteristik peserta didik jenjang SMA adalah pemikiran operasional formal bersifat lebih abstrak daripada pemikiran operasional konkret. Peserta didik jenjang SMA tidak lagi terbatas pada pengalaman nyata dan konkret sebagai landasan berpikirnya. Mereka mampu membayangkan situasi rekaan dan kejadian yang semata-mata berupa kemungkinan hipotesis atau pun proporsi abstrak, dan mencoba mengolahnya dengan pemikiran logis (Santrock, 2003).

Berdasarkan beberapa pertimbangan mengenai penggunaan AR sebagai media pembelajaran. Berikut beberapa Materi Pembelajaran Sains pada jenjang SD, SMP, SMA yang pernah mengaplikasikan media pembelajaran dengan menggunakan teknologi AR.

a. Pada Jenjang SD sederajat

1) Materi Pengenalan Panca Indra pada siswa kelas IV SD. Berdasarkan hasil penelitian disebutkan bahwa pengembangan aplikasi multimedia presentasi pembelajaran panca indra dengan teknologi AR dapat digunakan oleh guru sebagai alat bantu pengajaran di kelas dan dapat membantu siswa lebih memahami pelajaran IPA khususnya struktur dan fungsi panca indra manusia. Multimedia presentasi pembelajaran dengan teknologi AR dapat diterapkan untuk menggantikan metode pembelajaran konvensional (Sari, 2012).

2) Materi pengelompokan hewan berdasarkan makanannya pada siswa kelas III SD. Berdasarkan penelitian disebutkan bahwa pembelajaran IPA menggunakan Augmented Reality (AR) berbasis android secara keseluruhan memperoleh respon yang baik dimana menurut siswa media yang telah dikembangkan sudah sangat menarik, baik dari segi desain, jenis huruf, kejelasan gambar 3D dan penggunaan bahasa (Saputri, 2018).

Berdasarkan studi literatur yang telah dilakukan, ada beberapa materi pada pembelajaran sains SD yang bisa disampaikan menggunakan teknologi Augmented Reality diantaranya Materi Panca Indra yang diajarkan kepada siswa kelas IV SD. Augmented Reality dapat membantu peserta didik mengenal lebih dalam lagi Panca Indra yang mereka miliki dan meningkatkan pemahaman peserta didik terhadap bagian Panca Indra yang sulit dilihat langsung oleh mata. Contoh pembelajaran sains SD yang lainnya yaitu Materi Pengelompokan Hewan pada siswa kelas III SD, karakteristik peserta didik 
yang sudah mampu berimajinasi terhadap objek yang divisualisasikan dapat dimaksimalkan dengan visualisasi yang diberikan oleh Augmented Reality dibandingkan dengan hanya menampilkan gambar-gambar hewan 2 dimensi, sehingga peserta didik akan jauh lebih tertarik dengan visualisasi Augmented Reality. Hal ini dapat memberikan pengalaman belajar tersendiri bagi peserta didik.

b. Pada Jenjang SMP Sederajat

1) Materi sistem Tata Surya jenis, tekstur dan lapisan yang ada di dalam planet yang dikembangkan untuk siswa kelas VII- IX Sekolah menengah pertama. Berdasarkan hasil penelitian disebutkan bahwa aplikasi pembelajaran interaktif dengan menggunakan teknologi Augmented Reality berdampak positif bagi siswa SMP Negeri 57. Mempermudah guru menjelaskan kepada siswa dan lebih mendekatkan guru kepada siswa karena saling belajar menggunakan aplikasi yang baru bagi mereka (Rosa, 2019).

2) Materi Sistem Rangka, berdasarkan hasil penelitian disebutkan bahwa dalam proses belajar mengajar, guru hanya memberikan materi pelajaran IPA Biologi di dalam kelas tanpa penggunaan media teknologi, seperti komputer atau smartphone, sehingga beberapa siswa kurang berminat dan sering sengaja tidak mengikuti proses belajar mengajar sehingga nilai yang didapatkan lebih rendah dari yang diharapkan. Selain itu, mata pelajaran IPA Biologi seharusnya diajarkan juga melalui kegiatan praktikum di laboratorium. Namun kegiatan praktikum mengalami kendala karena alat peraga yang ada terbatas (Areani, 2018:107), dengan menggunakan teknologi AR permasalahan tersebut dapat diatasi.

Berdasarkan studi literatur yang sudah dilakukan, pada jenjang SMP materi yang bisa disampaikan menggunakan Augmented Reality adalah materi mengenai Sistem Tata Surya dan Sistem Rangka. Penggunaan Augmented Reality dalam penyampaian kedua materi tersebut dinilai berhasil meningkatkan pemahaman peserta didik karena dengan menggunakan Augmented Reality objek-objek virtual secara menarik seperti planet, galaksi, yang dapat dihadirkan di depan kelas.

c. Pada Jenjang SMA Sederajat

1) Materi virus pada siswa kelas $X$, berdasarkan hasil penelitian disebutkan bahwa hasil pengujian User Acceptance Testing, yaitu pretest dan posttest yang telah dilakukan, untuk kelompok siswa yang belajar menggunakan buku biologi memiliki persentase kenaikan dari nilai pretest ke posttest sebesar $20,06 \%$, sedangkan untuk kelompok siswa yang belajar menggunakan aplikasi Augmented Reality virus memiliki persentase kenaikan dari nilai Pretest ke posttest sebesar $25,31 \%$, yang berarti Augmented Reality dapat diterapkan sebagai media pembelajaran virus (Mesililesi, 2017).

2) Materi pembelahan sel pada siswa kelas XII. Berdasarkan penelitian tersebut hasil pengujian pretest dan posttest yang telah dilakukan, untuk kelompok siswa yang belajar menggunakan media buku biologi memiliki persentase 
kenaikan nilai sebesar 58\%, sedangkan pada kelompok belajar menggunakan aplikasi Augmented Reality memiliki persentase kenaikan nilai sebesar $87.26 \%$, yang berarti teknologi Augmented Reality dapat diterapkan sebagai media pembelajaran pembelahan sel (Haryanto, 2017).

3) Materi sistem saraf pada siswa kelas XI. Berdasarkan hasil penelitian disebutkan Hasil pengujian pretest dan posttest, kelompok siswa yang belajar menggunakan buku biologi memiliki kenaikan persentase nilai sebesar $26.48 \%$ sedangkan kelompok siswa yang belajar menggunakan aplikasi Augmented Reality memiliki persentase nilai sebesar $36.10 \%$ yang berarti aplikasi Augmented Reality sistem saraf pusat manusia dapat diterapkan sebagai media pembelajaran sistem saraf pusat manusia ((Mustaqim, Ilmawan., 2018).

Berdasarkan studi literatur yang sudah dilakukan, materi pembelajaran sains yang dapat disampaikan menggunakan media Augmented Reality pada jenjang SMA adalah materi mengenai virus, pembelahan sel, dan materi mengenai berbagai sistem yang ada di dalam tubuh. Penggunaan media Augmented Reality di dalam penyampaian materi mengenai virus dan pembelahan sel dapat membantu peserta didik memahami mengenai struktur virus dan struktur sel sehingga dalam hal ini peserta didik akan jauh lebih paham bagian-bagian dari virus dan sel, yang dimana jika tidak menggunakan media Augmented Reality peserta didik hanya bisa melihat tampilan gambar 2 dimensi yang terkadang kurang jelas dan detail. Sedangkan penggunaan media Augmented Reality dalam materi mengenai sistem sistem gerak, sistem pencernaan, dan sistem saraf dapat membawa peningkatan hasil belajar peserta didik karena melalui media Augmented Reality segala proses mengenai sistem tersebut dapat divisualisasikan, sehingga hal ini mampu meningkatkan kemampuan berpikir kritis peserta didik SMA.

\section{SIMPULAN DAN SARAN}

Berdasarkan studi pustaka di atas dapat disimpulkan bahwa media pembelajaran sains dengan menggunakan teknologi dapat dijadikan pilihan terbaik untuk mempermudah dalam penyampaian materi. Disisi lain teknologi juga menemui banyak kendala antara lain, tidak adanya kesempatan kepada siswa untuk mengembangkan kemampuan psikomotorik, seperti belajar memasang, menggunakan, dan merakit instrumen praktikum secara langsung, merasa kurang paham dalam pembelajaran sains khususnya dalam hitungan. Dibutuhkannya inovasi media pembelajaran baru untuk mengatasi kendala tersebut. Teknologi Augmented Reality (AR) dapat dijadikan sebagai alternatif karena teknologi tersebut yang dapat dimanfaatkan sebagai media pembelajaran dengan menggabungkan objek visual dua maupun tiga dimensi kedalam sebuah dunia nyata yang akan dimunculkan secara real time, sehingga 3 kemampuan yang harus di kembangakan dalam pembelajaran sains, yaitu kemampuan untuk mengetahui apa yang diamati, kemampuan untuk memprediksi apa yang belum diamati, dan kemampuan untuk 
menguji tindak lanjut hasil eksperimen, dikembangkannya sikap ilmiah, dapat tersampaikan dengan baik. Teknologi Augmented Reality (AR) dapat diimplementasikan sebagai media pembelajaran pada beberapa materi pembelajaran sains antara lain materi fotosintesis, pengenalan panca indera, energi angin, dan pengelompokkan hewan berdasarkan makanannya (pada jenjang SD); materi sistem tata surya, tekstur dan lapisan yang ada di dalam planet, struktur bumi dan bencananya, dan sistem rangka (pada jenjang SMP); dan materi virus, sistem gerak, sistem pencernaan, sistem saraf, dan pembelahan sel (pada jenjang SMA). Berdasarkan telaah dari literatur yang telah dilakukan maka diperlukan penelitian lebih lanjut mengenai pengembangan AR sebagai media pembelajaran pada materimateri pembelajaran sains yang memiliki sifat abstrak dan memerlukan visualisasi. Selain itu, diperlukan penelitian lebih lanjut mengenai pengaruh penggunaan teknologi AR terhadap hasil belajar peserta didik agar dapat memotivasi para pendidik dan peneliti lain untuk mengembangkan AR.

\section{UCAPAN TERIMA KASIH}

Terima kasih kepada Ibu Destri Ratna Ma'rifah selaku dosen pembimbing kami. Terima kasih kepada segenap keluarga besar Pendidikan Biologi FKIP UAD yang telah mendukung kami dalam melaksanakan penelitian ini.Terima kasih kepada pihak Pendidikan Biologi UIN Walisongo yang telah memberikan kesempatan kepada kami untuk mempublikasikan hasil penelitian kami pada Bioeduca: Jurnal Pendidikan Biologi. Terimakasih kepada semua pihak yang mendukung penulisan jurnal ini, mulai dari proses pengambilan data, penulisan jurnal hingga publikasi.

\section{RUJUKAN}

Abidin, Z., Arizona, K., Barat, N. T., Studi, P., \& Fisika, T. (2020). Pembelajaran Online Berbasis Proyek Salah Satu Solusi Kegiatan Belajar Mengajar Di Tengah Pandemi Covid-19. Jurnal Ilmiah Profesi Pendidikan, 5(2502-7069), 64. https://doi.org/10.29303/jipp.v5i1.111

Areani, I. sari. (2018). Implementasi Metode Ajar Interaktif dengan Augmented Reality untuk Mata Pelajaran Biologi. Jurnal Tepat, 1(2). Diambil dari https://eng.unhas.ac.id/tepat/index.php/Jurnal_Tepat/article/view/27

Denker, K. . (2013). Student Responses System and Facilitating the Large Lecture Basic Communication. Assessing Engagement and Learning.

Dewi, K. R. (2019). Peserta Didik di Sekolah Dasar. Kompasiana. Diambil dari https://www.kompasiana.com/ratihkurnia/5dbe7159097f362b176ab4f2/karakt eristik-peserta-didik-di-sekolah-dasar?page=all.

Fitriani, Yani., D. (2020). Motivasi Belajar Mahasiswa Pada Pembelajaran Daring Selama Pandemik Covid-19. Jurnal Kependidikan, 6(2), 165-175. Diambil dari http://ojs.ikipmataram.ac.id/index.php/jurnalkependidikan/index

Haryanto, Tonny., D. (2017). Aplikasi Augmented Reality sebagai Media Pembelajaran Materi Pembelahan Sel dalam Mata Pelajaran Biologi. Jurnal 
Sistem dan teknologi Informasi, 5(2). Diambil dari https://jurnal.untan.ac.id/index.php/justin/article/view/19431

Husaini, M. (2019). "Pemanfaatan Teknologi Informasi Dalam Bidang Pendidikan (EEducation). Jurnal Mikrotik, 2(1). Diambil dari http://ojs.ummetro.ac.id/index.php/mikrotik/article/view/314/254.

Kementerian Pendidikan Nasional. (2006). Peraturan Menteri Pendidikan Nasional No. 23 Tahun 2006 Tentang Tujuan Pendidikan. Jakarta: Kementerian Pendidikan Nasional.

Mesililesi, Muhammad Iqbal., D. (2017). Penerapan Augmented Reality Sebagai Media Pembelajaran Virus dalam Mata Pelajaran Biologi Kelas X SMA (Studi Kasus: SMA Negeri 7 Pontianak). Jurnal Sistem da Teknologi Informasistem da Teknologi Informasi, 5(2).

Mustaqim, Ilmawan., D. (2018). Pengembangan Media Pembelajaran Pai Berbasis Augmented Reality. Jurnal Edukasi Elektro, 21(1), 59-72. https://doi.org/10.24252/lp.2018v21n1i6

Mustaqim, I. dan N. K. (2017). Pengembangan Media Pembelajaran Berbasis Augmented Reality. Jurnal Edukasi Elektro, 1(1), 37. Diambil dari https://core.ac.uk/download/pdf/324174351.pdf

Negeri, K. D. (2020). Pedoman Penerapan Masyarakat Produktif dan Aman Covid19. Diambil dari https://ditjenbinaadwil.kemendagri.go.id/wpcontent/uploads/2020/07/5.7.2-Pedoman-Masyarakat-Produktif-dan-AmanCOVID-19.pdf.

Rosa, Agmita Clara., D. (2019). Rekayasa Augmented Reality Planet dalam Tata Surya sebagai Media Pembelajaran Bagi Siswa SMP Negeri 57 Palembang. Jurnal Informatika GLobal, 10(1). Diambil dari http://ejournal.uigm.ac.id/index.php/lG/article/view/728

Santrock. (2003). Perkembangan Remaja. Edisi Keenam. Jakarta: Erlangga.

Saputri, Eka Fitriani, D. (2018). PENGEMBANGAN MEDIA PEMBELAJARAN IPA MENGGUNAKAN AUGMENTED REALITY (AR) BERBASIS ANDROID PADA SISWA KELAS III SDN 015 TARAKAN. Jurnal Pendidikan dan Pembelajaran Sekolah Dasar, 6(1). Diambil dari https://journal.trunojoyo.ac.id/widyagogik/article/view/4562

Sari, W. S., Ika Novita Dewi, dan A. S. (2012). Multimedia Presentasi Pembelajaran Berbasis Augmented Reality untuk Pengenalan Panca Indra dalam Mendukung Mata Pelajaran IPA Tingkat Sekolah Dasar. SEMANTIK. Diambil dari http://publikasi.dinus.ac.id/index.php/semantik/article/view/62

Sofiah, R., Suhartono, \& Hidayah, R. (2020). Analisis Karakteristik Sain Teknologi Masyarakat (STM) Sebagai Model Pembelajaran: Sebuah Studi Literatur. Pedagogi: Jurnal Penelitian Pendidikan, 7(1), 1-18. https://journal.uniku.ac.id/index.php/pedagogi

Tafonao, T. (2018). Peranan Media Pembelajaran Dalam Meningkatkan Minat Belajar Mahasiswa. Jurnal Komunikasi Pendidikan, 2(2), 103. https://doi.org/10.32585/jkp.v2i2.113 
Yuliono, T., Sarwanto, S., \& Rintayati, P. (2018). Media Pembelajaran Augmented Reality terhadap Penguasaan Keefektifan Konsep Sistem Pencernaan Manusia. Jurnal Pendidikan Dasar, 9(1), 65-84. 